\title{
On eastern imperial eagle (Aquila heliaca) breeding in atypical habitat under competitive conditions with other eagle species
}

\author{
K hniezdeniu orla král'ovského (Aquila heliaca) v netypickom prostredí \\ v konkurencii s inými druhmi orlov
}

\author{
Rinur H. BEKMANSUROV, Igor V. KARYAKIN \& Elena P. SHNAYDER
}

\begin{abstract}
In the paper we describe two cases of eastern imperial eagle breeding in the former nests of greater spotted eagle and white-tailed eagle observed in the Tatarstan Republic, Russia. In both cases, eastern imperial eagles occupied non-favourable habitats they never used before - a vast alder forest in the wetlands and an island in a reservoir. The possible reasons that made the eagles expand their breeding ranges in the Volga region of Russia are discussed in this paper.
\end{abstract}

Abstrakt: V príspevku popisujeme dva prípady hniezdenia orla královského $\mathrm{v}$ hniezdach po orlovi hrubozobom a orliakovi morskom, pozorované v Tatárskej republike v Ruskej federácii. Orol královský obsadil, v oboch prípadoch, suboptimálne habitaty, ktoré doteraz takto nevyužíval - rozsiahle slatinné jelšiny a ostrov na vodnej nádrži. V práci rozoberáme možné príčiny stojace za rozširovaním hniezdneho areálu druhu v ruskom Povolží.

Key words: Aquila heliaca, Aquila clanga, Haliaeetus albicilla, interspecific competition, nest sites

\begin{abstract}
Rinur H. Bekmansurov, Elabuga Institute, Kazan Federal University; National Park "Nizhnyaya Kama", 89 Kazanskaya Str., 423607 Elabuga, Republic of Tatarstan, Russia. E-mail: rinur@yandex.ru.

Igor V. Karyakin, Elena P. Shnayder, Siberian Environmental Centre, 33 Irtiishskaya Str., 630060 Novosibirsk, Russia.

Acknowledgements: This work was supported by the Rufford Foundation (Rufford Small Grant) and by the Ministry of Forestry of the Republic of Tatarstan. We are grateful to Eugene Kostin, Renat Rachmatullin, Radik Kutushev, Nadezhda Bekmansurova and Dmitry Zhukov for their help in the field work. We are thankful to Benjamín Jarčuška for his help with editing our manuscript and his valuable comments on the text, and two anonymous reviewers for their critical reading and notes.
\end{abstract}

\section{Introduction}

The eastern imperial eagle is a globally endangered species, in Europe threatened with extinction. In Europe its population is estimated to be between 1,000 and 1,600 breeding pairs (Horvath et al. 2002). Meanwhile in the European part of Russia a rather dense population of this species still persists, with numbers estimated to be between 1,100-1,500 breeding pairs (Karyakin et al. 2013), and with half of this population located in the Volga Region (610-720 pairs). The endangered status of the eastern imperial eagle has stimulated numerous studies on its ecology, behaviour and distribution ranges. Our group is studying eastern imperial eagles in the Tatarstan Region of Russia within the project on raptor study and conservation in Russia. Besides the eastern imperial eagle (EIE; Aquila heliaca) there are two other eagle species that breed in the Tatarstan Republic: the white-tailed eagle (WTE; Haliaeetus albicilla) and the greater spotted eagle (GSE; Aquila clanga). With its adaptive capabilities on the back- ground of its changing environment, the EIE stands out against the two other eagle species, which is a conclusion from our observations of EIE settling in atypical habitats as described in this paper.

I mperial e a g le e cology a n d $\mathrm{n}$ e s t ing habit s

The forest steppe landscapes of the Tatarstan Republic are favorable for high abundance of EIE. In the Volga Region EIE is a migratory species that inhabits its breeding ranges from the end of March-beginning of April till the end of October. The estimated number of the population in Tatarstan in 2013 was $140-160$ breeding pairs (Bekmansurov et al. 2013; Karyakin at al. 2013). EIE breeds mainly in the forest edges bordering the steppe and in agricultural areas (Fig. 1). There are 5 main types of EIE breeding habitats: i) native pine and mixed forests $(48.3 \%)$; ii) artificial shelterbelts in agricultural landscapes $(23.3 \%)$; iii) small groves of fineleaved wood species or solitary trees in agricultural 

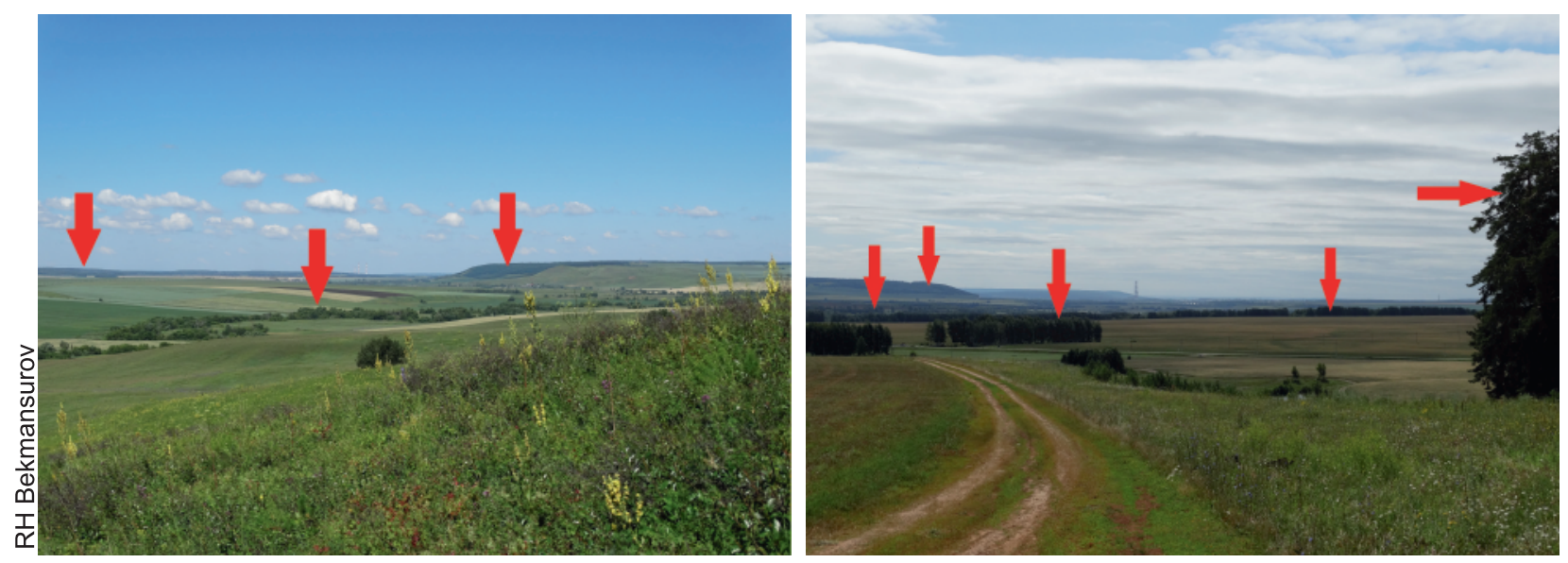

Fig. 1. Forest steppe areas in the Volga Region are the typical habitat of eastern imperial eagle. Arrows in the pictures mark the most appropriate sites for eastern imperial eagle nests.

Obr. 1. Lesostepné územia v Povolží sú typickým habitatom orla král'ovského. Šípky označujú najvhodnejšie miesta pre hniezda orla král'ovského.

landscapes (20\%); iv) black poplar (Populus nigra) groves in the small river valleys $(6.7 \%)$; v) anthropogenic landscapes like cemeteries and power supply infrastructure (6.7\%) (Fig. 2) (Bekmansurov \& Karyakin 2013). Nests are predominantly built in birches $(40 \%)$ and in pines $(30 \%)$ in the upper parts of the trees, and less often in poplars, oaks, limes, alders, elms, willows and spruces. Eastern imperial eagles use their nests for many years. Some pairs have 2 or 3 nests in the same territory. The mean distance between nests of neighboring pairs of EIE in the study region is $4.8-5.5 \mathrm{~km}$. The minimum distance is $2.2 \mathrm{~km}$ (found in mixed pinebroad-leaved forest).

The basic prey species of EIE are large-toothed suslik (Spermophilus major), spotted suslik (Spermophilus suslicus), bobak marmot (Marmota bobak), European hamster (Cricetus cricetus) and different kinds of corvids (Corvidae) (Bekmansurov \& Karyakin 2013).

\section{White-tailed e a g le e colog y} a n d n e s t i ng habit s

WTE is a dominant species of raptor in riverside habitats. Since this species is resident in the Volga Region, WTE return to their home ranges earlier than any other eagles, and begin to hatch in the middle of March. The estimated number of WTE population is 160 breeding pairs, with the home ranges of 146 pairs currently known. There are two main types of WTE breeding habitats: woodlands in the flood-plains of the Rivers Volga and Kama and islands in the Kuybyshevo Reservoir $(61 \%)$ (Fig. 3b), and forests that cover the banks of the Volga and Kama Rivers (35\%) (Fig. 3a). Finally, a third type of habitat is found in agricultural lands, where eagles breed in shelterbelts located not less than $4 \mathrm{~km}$ away from the water (4\%). Nests of WTE are built in pines $-29.9 \%$, poplars $-33.3 \%$, willows $-25.3 \%$, oaks $-4.6 \%$, limes $-2.3 \%$, and also in alders, elms, aspens and birches. Under the most favourable conditions WTE makes dense breeding populations in which the distance between the closest nests could be $0.37 \mathrm{~km}$ (Bekmansurov et al. 2012). In other locations the mean distance between the closest pairs varies from 2 to $20 \mathrm{~km}$. Most nests are used for several years. Each pair typically has only one nest, and very seldom two nests.

The basic prey species of WTE are fish, herons ( $A r$ dea cinerea), gulls (Larus sp.), waterfowl (Anseriformes, Podiceps cristatus), and muskrats (Ondatra zibethicus) (Bekmansurov et al. 2012).

Greater spotted e a g l e e c olog y a n d n e st ing habits

The population number of the GSE in the region is much lower than that of the two other eagle species (Askeev \& Askeeva 1999). A considerable part of its habitat was submerged with the creation of the Kuybyshevo Reservoir in 1955. Before this happened GSE was a common species in the region (Zharkov \& Teplov 1932). Today the estimated number of GSE is 20-25 breeding pairs (Karyakin 2008). GSE is a migratory species in the Volga Region that inhabits its breeding ranges from the end of March-beginning of April onwards. The main type of GSE breeding habitat is wet- 


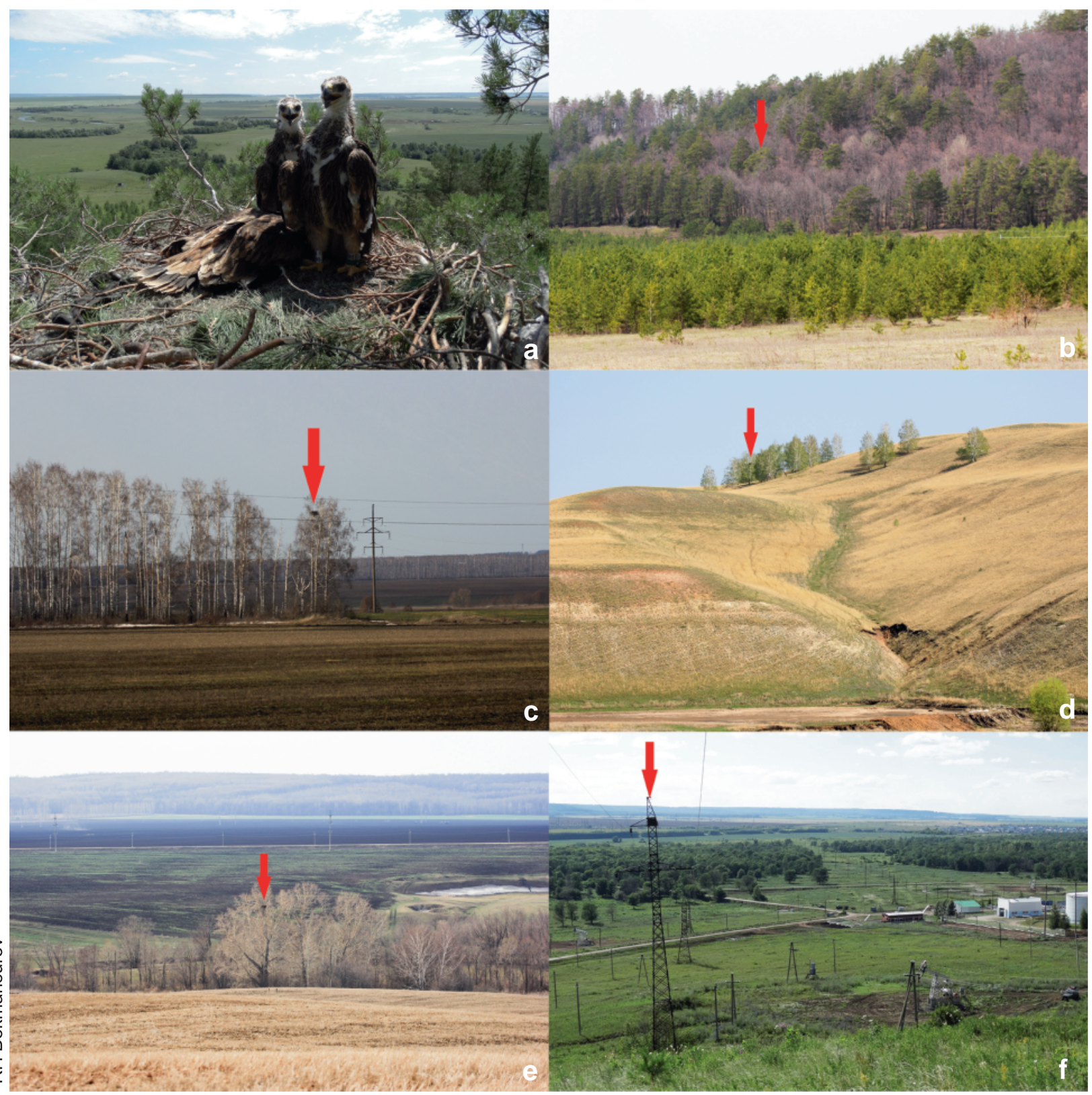

Fig. 2. Nests of eastern imperial eagles in different types of breeding habitats (arrows indicate location of nests): view of forest steppe landscape from the nest (a). Nest located in native mixed forest (b), shelterbelt (c), birch grove bordered with pasture on hill slope (d), nest located on poplar in small river valley (e), and nest located on power line pylon near oil-extracting facilities (f).

Obr. 2. Hniezda orlov král'ovských v rôznych typoch habitatov (šípky ukazujú na hniezdo): pohlad z hniezda na lesostepnú krajinu (a). Hniezdo situované v pôvodnom zmiešanom lese (b), vo vetrolame (c), brezovom háji obklopenom pastvinami na svahu kopca (d), hniezdo umiestnené na topoli $v$ malom riečnom údolí (e) a hniezdo umiestnené na elektrickom stĺpe $v$ blízkosti zariadenia na t’ažbu ropy (f).

land forests in the river valleys with lowland swamps that are contiguous with agricultural landscapes (Fig. 4a). The dominant tree species in such habitats is the black alder (Alnus glutinosa). Typically GSEs locate their nests in the middle third of a tree (5-10 m above the ground), avoiding open areas, so its nests are hidden in the forest canopy (Fig. 4b, 4c). GSE typically have only one nest. We observed only two pairs that pos- 


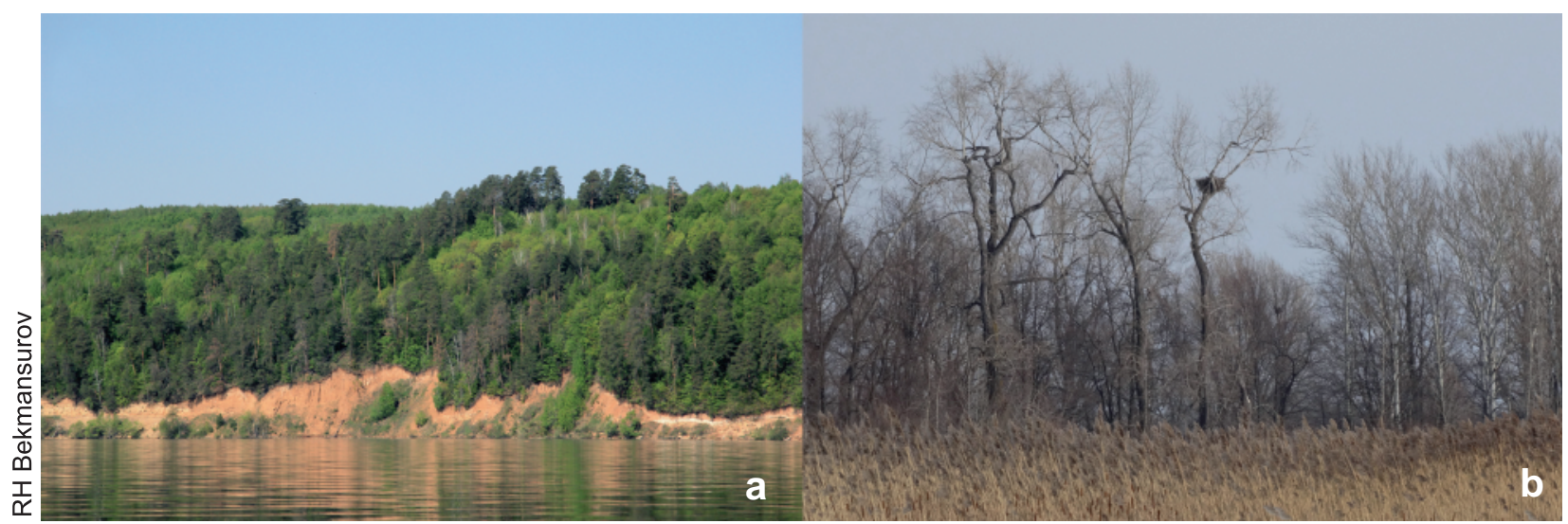

Fig. 3. Typical breeding habitats of white-tailed eagle in the Volga Region: forest on the bank of the River Kama (a), wetland forest covering an island in the Kuybyshevo Reservoir (b).

Obr. 3. Typický hniezdny habitat orliaka morského v Povolží: les na brehu rieky Kamy (a), slatinné lesy pokrývajúce ostrov na vodnej nádrži Kuybyshevo (b).

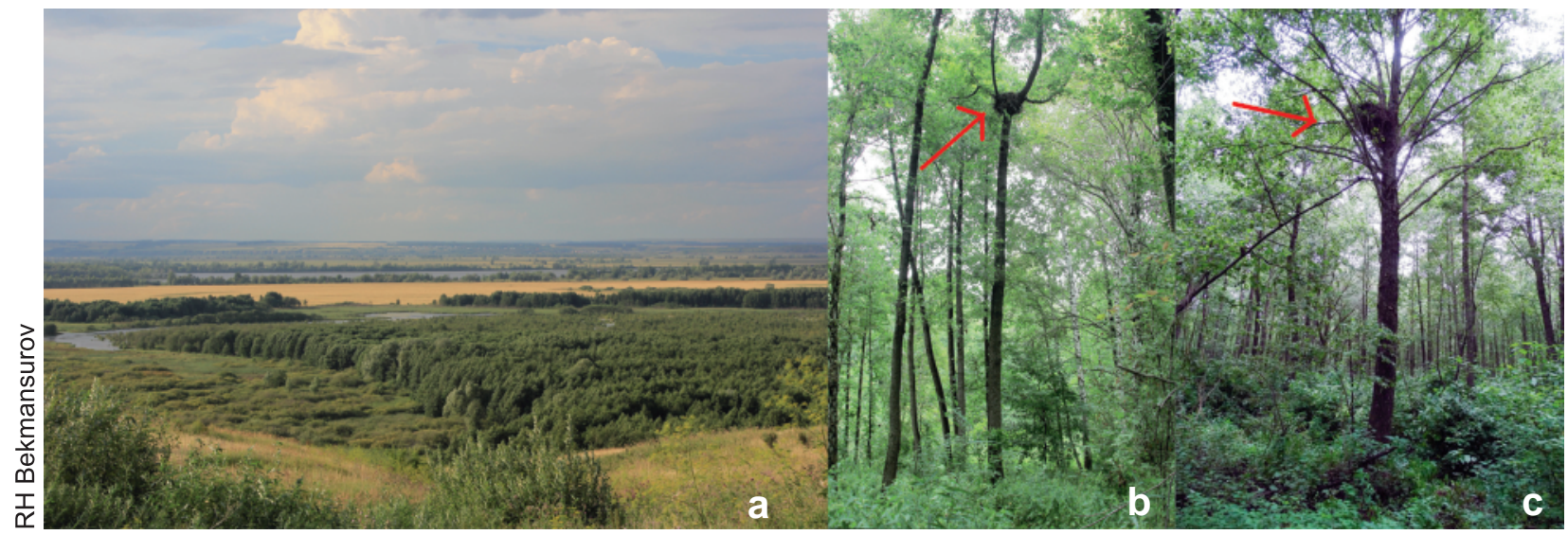

Fig. 4. Typical breeding habitat of the greater spotted eagle, wetland forest in the Kama River valley dominated by black alder (a), nest of the greater spotted eagle located in a black alder (arrow indicates the nest) (b, c).

Obr. 4. Typický hniezdny habitat orla hrubozobého, slatinný les v údolí rieky Kamy s dominantnou jelšou lepkavou (a) hniezdo orla hrubozobého umiestnené na jelši lepkavej (ukazuje naň šípka) (b, c).

sessed two nests in the territory.

The basic prey species of GSE are European water voles (Arvicola amphibius), corvids (Corvidae) and grey herons (Zharkov \& Teplov 1932, Bekmansurov et al. 2013).

\section{Material and methods}

S t u d y a r e a

The study area is located in the western part of the Tatarstan Republic $\left(55^{\circ} 17^{\prime} \mathrm{N}, 49^{\circ} 38^{\prime} \mathrm{E}\right)$, Volga Region, Russia (Fig. 5). It encompassed the islands in the Kuybyshevo Reservoir and the shore line up to $15 \mathrm{~km}$ inland (in total about $1,700 \mathrm{~km}^{2}$ ). The climate is moderately continental, with warm, sometimes hot summer seasons and moderate frosts in winter. The mean temperature in July is $18-20^{\circ} \mathrm{C}$, and in January it is $-13^{\circ} \mathrm{C}$. The average annual precipitation is $460-540 \mathrm{~mm}$. It is predominantly a plain with the mean altitude varying from $170 \mathrm{~m}$ to $180 \mathrm{~m}$ a.s.l. with the highest elevations (up to $223 \mathrm{~m}$ a.s.1.) situated on the right bank of the Volga.

The reservoir and its islands was created in 1955-1957 in the middle part of the Volga and lower Kama by the dam of the Zhiguly Hydroelectric Station. Most of its islands are covered with inundated forests 
dominated by black poplar and willow (Salix sp.). Only one island, the Ivanovskiy island (Fig. 5), is covered with coniferous forest. The left bank of the Volga (and Kuybyshevo Reservoir) is covered with small woodlands dominated by small-leaved lime (Tilia cordata) and Scots pine (Pinus sylvestris). The mouth of the River Bezdna (Fig. 5) that flows into Volga is surrounded with woodlands dominated by the black alder. A forest steppe zone with mixed forests and small areas of pure pine forests, which is the dominant type of habitat in the region, stretches some distance from the banks. In the agricultural land that covers $67.8 \%$ of the territory, fields are bounded with artificial shelterbelts consisting of silver birches (Betula pendula) white birches (B. pubescens), Scots pines, European white elms (Ulmus laevis) and black poplars. The total wood coverage of the territory is $25 \%$ at most.

\section{F i e 1 d w o r k}

Systematic yearly monitoring of raptor species populations has been carried out since 2010 in the Tatarstan Republic. In 2012-2014 we conducted a thorough monitoring of occupation status and breeding attempts in formerly known territories, as well as systematic surveys for the new settlers.

In this area, 34 home ranges of WTEs, 11 of EIEs and 3 of GSEs are known. Breeding territories of WTE are mostly situated on the islands and in the riverside forest edges. There are only two exceptions: one nest situated in a shelterbelt in the middle of agricultural land, and another one in pine forest located more distantly from the river. Apart from two cases described below, EIE prefer edges of coniferous and mixed forests and shelterbelts in agricultural lands. All GSE breeding territories are situated in the wetland forest in the Bezdna valley, dominated by the black alder.

\section{Results and discussion}

In 2012-2014 during population monitoring of birds of prey we came across two cases of nesting by eastern imperial eagles in unusual habitats when pairs occupied nests of other raptor species.

In the first case, a pair of EIEs occupied a former greater spotted eagle nest situated in wetland forest (around $5 \mathrm{~km}^{2}$ ) dominated by the black alder in the Spasskiy Region, $4.6 \mathrm{~km}$ to the south from Kuybyshev Reservoir (Fig. 5). The distance between the nest tree and the edge of the bog was $560 \mathrm{~m}$, and around $700 \mathrm{~m}$ from an agricultural area. The nest was built in a crown bifurcation of an alder around $20 \mathrm{~m}$ above the ground.

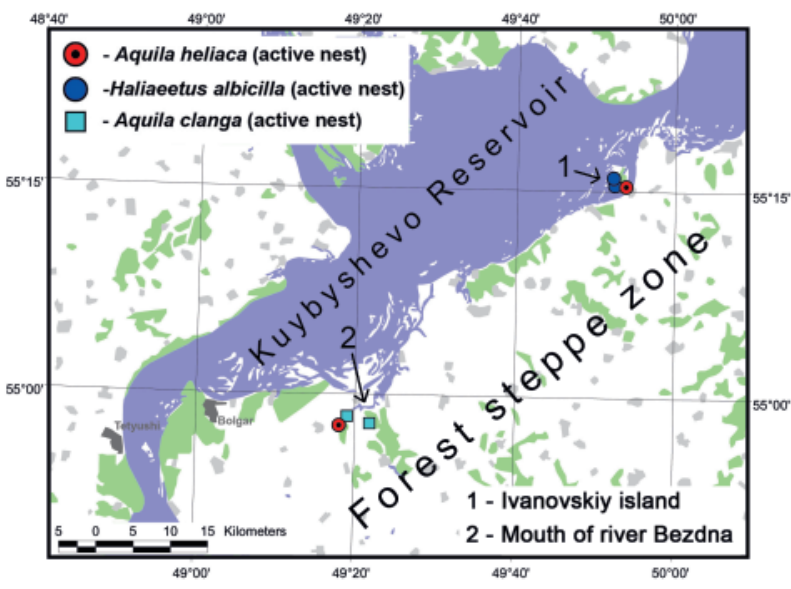

Fig. 5. Localization of the former nests of white-tailed eagles (1) and greater spotted (2) occupied by eastern imperial eagles, and the neighbouring nests of white-tailed eagle and greater spotted eagle in the surroundings of the Kuybyshevo Reservoir. Obr. 5. Lokalizácia bývalých hniezd orliaka morského (1) a orla hrubozobého (2) obsadených orlmi král'ovskými; susedné hniezda orliaka morského a orla hrubozobého $v$ okolí vodnej nádrže Kuybyshevo.

Until 2011, it was occupied by GSE. EIEs later built on an additional $30 \mathrm{~cm}$ layer of alder branches and successfully fledged one eaglet. We observed it at the age of 60 days on July 26th, 2012. In 2013 the same pair of EIEs fledged two youngsters, and in 2014 just one (Fig. 6).

One more GSE breeding territory was found in the vicinity, $4 \mathrm{~km}$ to the east from the nest occupied by EIE. GSEs from that nest produced one eaglet per year in 2012 and 2013. Another empty GSE nest was found 1.6 $\mathrm{km}$ to the north. According to our estimations two more pairs of GSE could occupy the same habitat, but their nests have not yet been found. Swamped alder forest is a typical habitat for GSE, but not for EIE. No cases of EIE breeding in such habitat had been identified before. The closest home ranges of EIEs were situated $9.9 \mathrm{~km}$ $\mathrm{SE}$ on the forest edge and another one $10.6 \mathrm{~km}$ to the west in the shelterbelt forest.

On the other hand, the location of the nest under discussion differed slightly from the typical position of a GSE nest in a tree. Typically, GSE place theirs nests in the middle part (the middle third) of an alder 5-10 m above the ground. But in this case the nest was built in the apical part of the tree, thus becoming visible from the air. We propose that the abnormal location of the nest was the main reason that provoked EIEs to occupy it. 

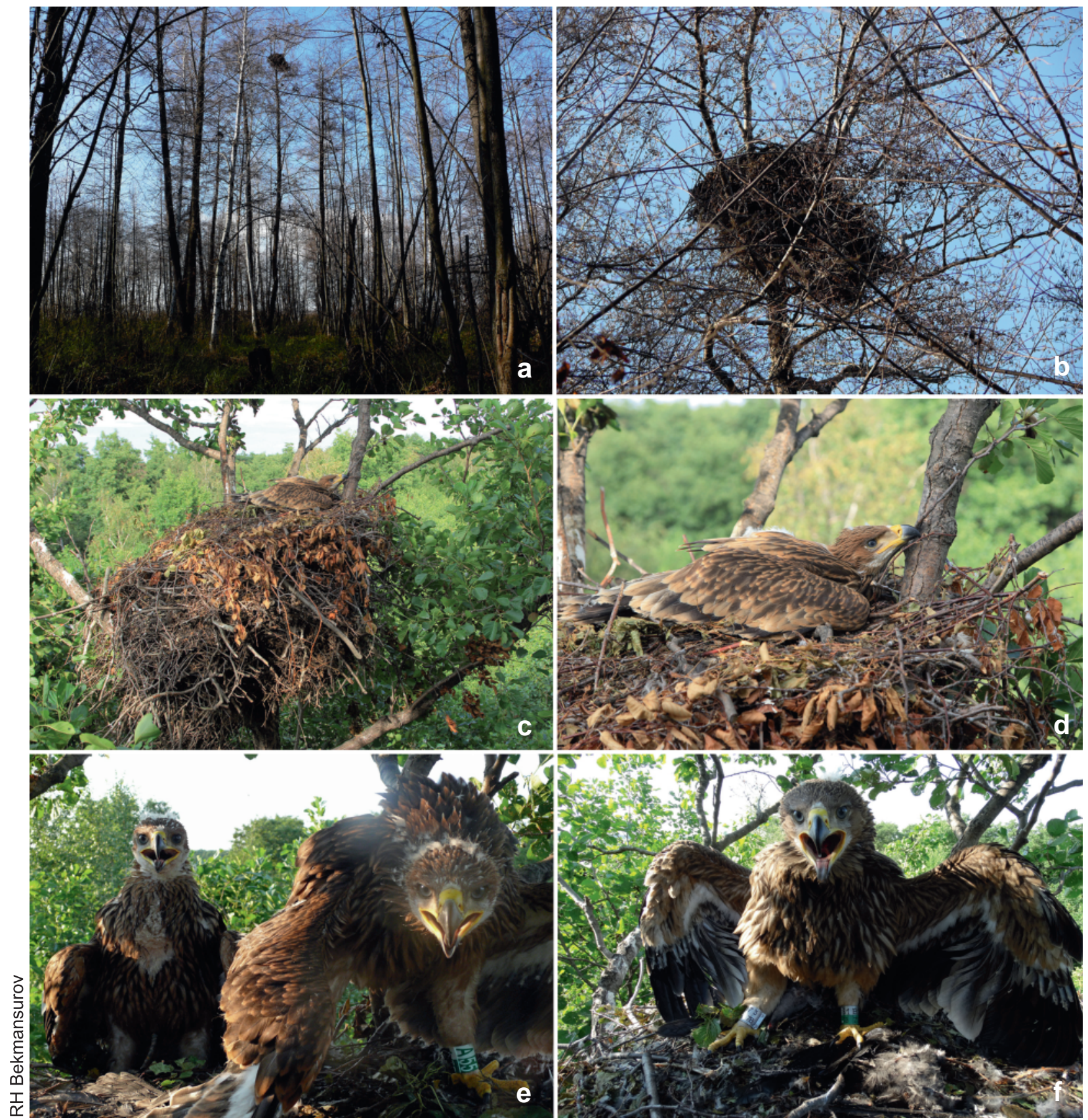

Fig. 6. Wetland forest at the mouth of the River Bezdna, 2011, with the nest of a greater spotted eagle (a). Nest of greater spotted eagle on the top of a black alder (b), in 2011 this nest was occupied by greater spotted eagles. The same nest with an eaglet of the eastern imperial eagle, 2012 (c, d), in 2013 with two eaglets of the eastern imperial eagle (e), and in 2014 with one eaglet of the eastern imperial eagle (f).

Obr. 6. Slatinné lesy v ústí rieky Bezdna, v roku 2011, s hniezdom orla hrubozobého (a). Hniezdo orla hrubozobého na vrcholci jelše lepkavej (b), v roku 2011 obsadené týmto druhom. To isté hniezdo s jedným mlád'at'om orla král'ovského v roku 2012 (c, d), v r. 2013 s dvoma mlád'atami (e), v r. 2014 s jedným mlád'at'om orla král'ovského (f).

Greater spotted eagles were seen at a distance of $1.2-1.5 \mathrm{~km}$ from their former nest in 2012-2014, which means that they still consider the nest site, since occupied by EIEs, as a potential nesting area. 

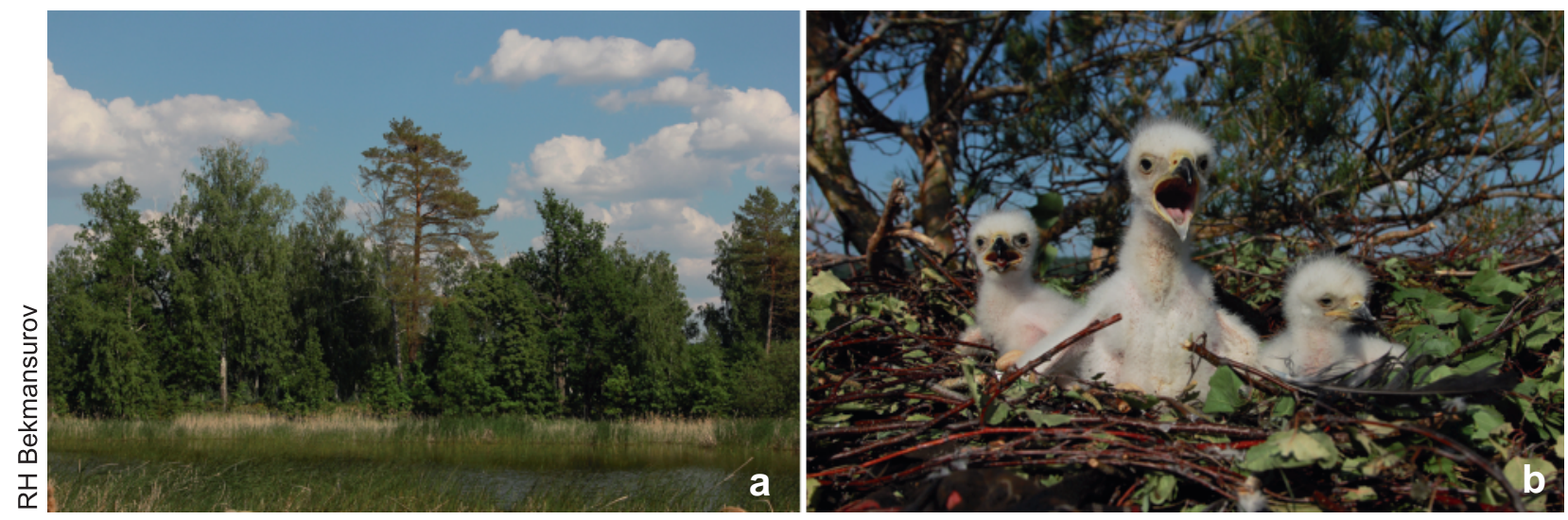

Fig. 7. Nest of white-tailed eagle in a pine tree on the Ivanovskiy Island occupied by eastern imperial eagles, 2013 (a); eaglets of eastern imperial eagle on the same nest, 2013 (b).

Obr. 7. Hniezdo orliaka morského na borovici na ostrove obsadené orlom král'ovským, 2013 (a); mlád'atá orla král'ovského na tom istom hniezde v r. 2013 (b).

The next case of a pair of EIEs using the nest of another raptor species was discovered during monitoring of the known nests of white-tailed eagles on Ivanovskiy Island in Kuybyshev Reservoir (Alekseeyevskiy Region) (Fig. 5). The size of the island is $5.87 \mathrm{~km}^{2}$ and the whole surface is covered in woods. Ivanovskiy Island is separated from the mainland by a channel $700 \mathrm{~m}$ wide. On March 3, 2013 we surveyed the forest on the island and found three nests of WTE all built in the tops of Scotch pines and seven individuals of different ages. Two nests out of the three were occupied by two breeding pairs of WTE; the third one remained vacant due to the death of both mates caused by poachers. The distances between the empty nest and the two others were $1.4 \mathrm{~km}$ and $2 \mathrm{~km}$, and the distance between the occupied nests was $1 \mathrm{~km}$. On repeated surveying of the same area on June 1, 2013, we found three nestlings of EIE in the age of two weeks in the third nest (Fig. 7). As in the first case described above, eastern imperial eagles built on this nest with a fresh layer of twigs. This time the thickness of this layer was only $0.1-0.15 \mathrm{~m}$.

We have no previous data about EIEs breeding on the islands of Kuybyshevo Reservoir. The closest EIE nest is situated on the mainland $8.4 \mathrm{~km}$ SE from Ivanovskiy Island in a pine shelterbelt on the bank of a small river near a farm with pasture land.

We checked the reproductive success of WTE from the other two nests located on the island as well, and confirmed the fidelity of the birds. In the closest nest situated $1.4 \mathrm{~km}$ from the eastern imperial eagle nest, both birds were shot dead and left under the nest by poachers. Fortunately, adult WTEs from the second nest were alive, as well as both eaglets.

Both cases described above had happened due to special circumstances. In the first case the main role was played by the non-typical placement of the nest in the upper part of a tree, which is unusual for greater spotted eagles, but it was the point that made this nest so attractive for eastern imperial eagles. Normally, greater spotted eagles build their nests much lower, in the middle part of the alder.

In the next case, the main fact that allowed eastern imperial eagles to breed in the nest of WTE was the absence of the former owners of the nest, the pair of WTEs shot dead by poachers. Normally, EIEs could not compete with WTE for nest sites because of the great difference in the dates of the beginning of their nesting seasons. WTE is a resident species that starts hatching at the end of February, while EIEs arrive in their home ranges only at the end of March.

From the previous observations it is known that EIEs could successfully compete with steppe eagles (Aquila nipalensis) for nesting sites situated in the forest shelterbelts or on the pylons of power lines in the arid zones of the Aral-Caspian Depression and steppe areas of the western Ural Region of Russia (Daviigora 1999, Karyakin 2006, Karyakin et al. 2011). Several cases of competition for tree-based nest sites between eastern imperial and golden eagles (Aquila chrysaetos) have been observed in the mountainous areas of the AltaiSayan ecoregion of Russia (Karyakin et al. 2009, Karyakin et al. 2010a, Vazhov 2012). However, EIEs usually lose in confrontations with golden eagles.

In all cases observed previously, eagles competed for 
the nest sites situated in the habitats that were optimal for both species. The situation in the forest-steppe area of the Volga Region described in this article is completely different. In the study area, eastern imperial eagles had never shared habitats with other eagle species such as WTE and GSE. Even in the vast pine forests covering the Volga river terrace, the home ranges of imperial eagles were located on the outer edges of the forest bordering steppe areas, avoiding riverside zones that are the favorite habitat for WTE (Karyakin 1998, Borodin at al. 1999, Karyakin 2007, Karyakin et al. 2008, Bakka et al. 2010, Bekmansurov et al. 2010, Lapshin \& Spiridonov 2010, Yakovlev \& Isakov 2010). Thus the singularity of new facts of EIE breeding in atypical habitats in nests built by other raptor species described in this short article lies in the fact that these eastern imperial eagles chose non-favorable habitats they were never observed using before - a vast alder forest in the wetlands and an island in a reservoir. These cases emphasize the high adaptive capability of EIEs.

A possible reason for the appearance of EIEs in unusual habitats could be found in the growing population of this species. Our current estimation of the population size of EIEs in the region - 140-160 breeding pairs in 2010-2013 (Bekmansurov et al. 2013, Karyakin at al. $2013)$ - is 2.5 times higher than the one published in 2006 (30-50 pairs) (Askeev \& Askeev 2006). However, the lack of precise surveys of the EIE population in Tatarstan before 2010 prevents us from making a plain conclusion about the population growth in this country.

However, there is well-documented evidence of relocation of the EIE population in the Volga Region (Samara District, Ulyanovsk District and Tatarstan Republic) in the late $20^{\text {th }}$ and early $21^{\text {st }}$ century. The process that began in the 1990s involved EIEs settling in shelter belts in agricultural lands, with nests predominantly built on birches. At the same time, the numbers that continued breeding in the pine forests were affected negatively (Adamov 2010, Bekmansurov et al. 2010, 2013, Bekmansurov \& Karyakin 2013, Karyakin et al. 2008, Karyakin \& Pazhenkov 2008, 2010). Before that the two main types of eastern imperial eagle breeding habitats were i) pine and mixed coniferous-broadleaved forests on river terraces and in mountainous areas; ii) black poplar groves in small river valleys (Karyakin 2007, 2010, Karyakin et al. 2008, 2010b, Korepov \& Borodin 2010). In addition, since 2005 we have observed a growing number of eastern imperial eagles nesting on concrete electricity poles both in
Tatarstan and in the neighbouring regions (Bekmansurov \& Karyakin 2013, Bekmansurov et al. 2013, Karyakin \& Pazhenkov 2008, 2010, Korepov 2009). The expansion of this species into anthropogenic landscapes could be caused by the growing population, or it could be just resettlement of a stable population caused by some ecological reasons and facilitated by the high adaptive capability of EIEs.

Collapse of the main prey species populations (Spermophilus major, Spermophilus suslicus and Cricetus cricetus) occurring everywhere throughout the Volga Region at the turn of the $20^{\text {th }}$ and $21^{\text {st }}$ centuries (Kuzmin et al. 2011, Bakaeva \& Titiov 2012) could be another reason forcing EIEs to move to new habitats in search for new food sources. The areas situated in close proximity to the rivers and the shore of the Kuybyshevo Reservoir could be considered as good habitats due to their large extent and high prey abundance. We suppose that EIEs, whose home ranges lie close to water bodies could alter theirs predation patterns and switch from predation on rodents to fowl that is abundant on reservoir shores and river banks. Today all three eagle species inhabiting this area prey on grey herons and gull species (Laridae), which is confirmed by the prey and pellets analysis of eastern imperial and white-tailed eagles and observations from the video-cameras installed on the nests of GSEs (unpublished).

$\mathrm{C}$ o n c l u s i o n s

The new cases of eastern imperial eagles breeding in atypical habitats that we currently witness in the Tatarstan Region could signalize the beginning of processes that could significantly change the distribution area of this species in the Volga Region. It could be either population expansion or population relocation in response to collapse of its basic prey species. In any case, eastern imperial eagles display adaptive behaviour flexibility in accommodation to their new environment, new diet, and strained interspecific relations with other eagle species.

\section{References}

Adamov S 2010: Monitoring of the imperial eagle breeding group in agricultural landscape near Dimitrovgrad, Russia. Raptors Conservation 20: 196-197.

Askeev O \& Askeev I 1999: Ornitofauna Respubliki Tatarstan (konspekt sovremennogo sostoyaniya) [Avifauna of Republic of Tatarstan (a summary of 
the current situation)]. Institute of Nature System Ecology, Kazan, 124. [In Russian].

Askeev O \& Askeev I 2006: Mogilnik [Imperial eagle], 80-81. In: Schepovskih AI (ed), Krasnaya kniga Respubliki Tatarstan [Red list of endangered species of Republic of Tatarstan]. Idel-press, Kazan, 832. [In Russian]

Bakaeva S \& Titov S 2012: Sovremennoye resprostraneniye krapchatogo suslika (Spermophilus suslicus) v Povolzhye: depressiya chislennosti i ecologicheskiye prichinii dinamiki arealaa [Current distribution of spotted suslik in Volga Region: population depression and ecological reasons for changes in distribution area]. Izvestiya Penzenskogo gosudarstvennogo pedagogicheskogo university imeni V G Belinskogo 29: 181-184. [In Russian with English summary]

Bakka S, Kiseleva N \& Karyakin I 2010: The imperial eagle in the Nizhniy Novgorod District, Russia. Raptors Conservation 20: 84-88.

Bekmansurov R \& Karyakin I 2013: Results of monitoring of the imperial eagle population in the Republic of Tatarstan in 2011-2012, Russia. Raptors Conservation 26: 84-108.

Bekmansurov R, Karyakin I, Pazhenkov A \& Nikolenko E 2010: The imperial eagle in the Republic of Tatarstan, Russia. Raptors Conservation 20: 119-127.

Bekmansurov R, Ayupov A, Karyakin I \& Kostin E 2012: Results of the monitoring of the white-tailed eagle populations in some protected areas and adjacent territories in the Republic of Tatarstan in 2012, Russia. Raptors Conservation 25: 79-96.

Bekmansurov R, Karyakin I, Ayupov A, Kostin E, Rachmatullin R \& Kutushev R 2013: Monitoring results of the large raptors in the Republic of Tatarstan in 2011-2013. Raptors Conservation 27: 122-145.

Borodin O, Smirnova S, Sviridova T, Korolkov M, Barabashin T, Kishkinev D, Ilyina D, Asanov A, Karatsuba D \& Ryzhenkov A 1999: Sovremennoye sostoyaniye orla-mogilnika v Ulyanovskoy oblasti [Recent status of the imperial eagle in the Ulyanovsk Region], 68-73. In: Belik V (ed), Imperial eagle: Distribution, population status and conservation perspectives within Russia. Bird Conservation Union, Moscow, 166. [In Russian with English summary]

Daviigora A 1999: Territorialnoye rezmescheniye i osobennosti gnezdovaniya orla-mogilnika v stepyakh Yuzhnogo Urala [Imperial eagle distribution and nesting features in the steppe areas of southern Ural], 82-83. In: Belik V (ed), Imperial eagle: distribution, population status and conservation perspectives within Russia. Bird Conservation Union, Moscow, 166. [In Russian with English summary]

Horvath M, Haraszthy L, Bagyura J \& Kovacs A 2002: Eastern imperial eagle (Aquila heliaca) population in Europe. Aquila 107-108: 193-204.

Karyakin I 1998: Pernatiye khischniki uralskogo regiona: sokoloobrazniye i sovoobrazniye [Raptors of the Ural Region: Falconiformes and Strigiformes]. Center poleviih issledovaniy soyuza okhranii zhivotniih Urala, Perm, 483. [In Russian]

Karyakin I 2006: Expansion of the imperial eagle onto power lines in western Kazakhstan. Raptors Conservation 7: 62-64.

Karyakin I 2007: Populatsionnaya struktura areala vostochnoyevropeyskogo mogilnika V VolgoUralskom regione i eyo dinamika $\mathrm{v}$ posledneye stoletiye [Population structure of the eastern imperial eagle range in the Volga-Ural Region and its trend during last 100 years], 163-171. In: Dimitriev A (ed), Proceedings of All-Russian conference "Bird research in the territory of the Volga-Kama region". Cheboksary. Ekologicheskiy vestnik Chuvashskoy respubliki [Ecological Newsletter of the Republic of Chuvashia] 57, 370. [In Russian]

Karyakin I 2008: The greater spotted eagle in the Volga Region, Ural Mountains and Western Siberia. Raptors conservation 11: 23-69.

Karyakin I 2010: Using GIS-software for estimation of number and forecasting the distribution of breeding raptors: approbation of methods for examples of analysis of distribution of the imperial eagle and golden eagle in the Volga-Ural Region, Russia. Raptors Conservation 19: 97-135.

Karyakin I \& Pazhenkov A 2008: Khischniye ptitsii Samarskoy oblasti [Birds of prey of the Samara District]. Ministry of natural resources and environment of the Samara District, Samara, 66. [In Russian]

Karyakin I \& Pazhenkov A 2010: The imperial eagle in the Samara District, Russia. Raptors Conservation 20: 97-118.

Karyakin I, Nikolenko E, Levin A \& Kovalenko A 2008: Imperial eagle in Russia and Kazakhstan: Population status and trends. Raptors Conservation 14: 18-27. 
Karyakin I, Nikolenko E, Vazhov S \& Bekmansurov R 2009: Imperial eagle in the Altai Mountains: results of the research in 2009, Russia. Raptors Conservation 16: 129-138.

Karyakin I, Nikolenko E, Barashkova A, Smelansky I, Konovalov L, Grabovskiy M, Vazhov S \& Bekmansurov R 2010a: Golden eagle in the Altai-Sayan Region, Russia. Raptors Conservation 18: 82-152.

Karyakin I, Pazhenkov A, Moshkin A, Barabashin T, Korolkov M \& Bekmansurov R 2010b: The imperial eagle in the Ural Region, Russia. Raptors Conservation 20: 128-145.

Karyakin I, Kovalenko A, Levin A \& Pazhenkov A 2011: Eagles of the Aral-Caspian Region, Kazakhstan. Raptors Conservation 22: 92-152.

Karyakin I, Bekmansurov R \& Nikolenko E 2014: Imperial eagle in Russia and Kazakhstan: monitoring results 2008-2013, 66-67. In: Deutschova L \& Guziová Z (eds), Abstracts of contributions presented in the VII. International conference on the conservation of the eastern imperial eagle, Bratislava, Slovakia, 2013. Slovak Raptor Journal 8 (1): 61-71. DOI: 10.2478/srj-20140001.

Korepov M 2009: Records of the imperial eagle atypical nesting in the south of the Ulyanovsk District, Russia. Raptors Conservation 16: 161-163.
Korepov M \& Borodin O 2010: The monitoring of the nesting groups of imperial eagles in the "Privolzhskaya Forest-Steppe" and "Watershed of Malaya Sviyaga River" important bird areas in 2010, Russia. Raptors Conservation 20: 48-53.

Kuzmin A, Shmyrov A \& Titov S 2011: Bolshoy suslik (Spermophilus major) na pravoberezhye Volgi: sovremennoye sostoyaniye i rasprostraneniye [The russet ground squirrel (Spermophilus major Pall.) on the Right bank of Volga: a modern condition and distribution]. Izvestiya Penzenskogo gosudarstvennogo pedagogicheskogo university imeni V G Belinskogo 25: 214-219. [In Russian with English summary]

Lapshin A \& Spiridonov S 2010: Modern population status of the imperial eagle in the Republic of Mordovia, Russia. Raptors Conservation 20: 93-96.

Vazhov S 2012: Some features of the ecological niches of raptors in the Russian part of the Altai foothills. Raptors Conservation 25: 115-125.

Yakovlev A \& Isakov G 2010: Distribution and number of the imperial eagle in the Republic of Chuvashiya at the beginning of XXI century. Raptors Conservation 20: 89-92.

Zharkov I \& Teplov V 1932: Materialii po pitaniyu khischniih ptits Tatarskoy respubliki [Data on diet of birds of prey in Tatarstan Republic]. Uchoniye zapiski Kazan university 92: 138-199. [In Russian] 